\title{
The Rise of Sino-Russian Order? Mapping China's and Russia's Geo-Economic Capabilities
}

\author{
Radityo Dharmaputra \\ Department of International Relations, Universitas Airlangga
}

\begin{abstract}
There is a growing debate about the emerging powers of China and Russia and the possibility of the two countries to balance the hegemony of United States in the world order. Based on the proposed geo-economical approach, I analyse the growing dynamics of China and Russia and compare the strengths and weaknesses of each countries' style of economic development. After analysing the strengths and weaknesses of both countries, I elaborate the possibility of conflict and cooperation between them. I argue about the probability of success and failure in the both countries' aspiration to balance the domination of United States. These dynamics, whether ending in challenging the U.S. hegemony or not, is likely to generate concerns, especially in the Asia-Pacific region. Therefore, I also elaborate the possible complications in the regions regarding the both countries' quest for power. In the end, I try to argue about the position of China and Russia related to the relative position of the United States, especially in the Asia-Pacific region.
\end{abstract}

Keywords: China, Russia, geo-economical approach, conflict, U.S. domination, balancing, Asia-Pacific region.

Ada perdebatan yang berkembang tentang munculnya tantangan dari Tiongkok dan Rusia dan kemungkinan kedua negara untuk mengimbangi hegemoni Amerika Serikat dalam tatanan dunia. Berdasarkan pendekatan geoekonomi, penulis menganalisis dinamika pertumbuhan Tiongkok dan Rusia serta membandingkan kekuatan dan kelemahan gaya pembangunan ekonomi masing-masing negara. Setelah menganalisis kekuatan dan kelemahan kedua negara, penulis menguraikan kemungkinan konflik dan kerjasama di antara mereka. Penulis mengelaborasi tentang kemungkinan keberhasilan dan kegagalan terkait aspirasi kedua negara untuk menyeimbangkan dominasi Amerika Serikat. Dinamika ini, terlepas apakah akan berakhir dengan tantangan terhadap hegemoni AS atau tidak, kemungkinan akan menimbulkan kekhawatiran terutama di kawasan Asia-Pasifik. Oleh karena itu, penulis juga menguraikan kemungkinan komplikasi di kawasan terkait upaya kedua negara untuk mendapatkan kekuasaan. Pada akhirnya, penulis mencoba melihat posisi Tiongkok dan Rusia terkait dengan posisi relatif Amerika Serikat, khususnya di kawasan Asia-Pasifik.

Kata-kata kunci: Tiongkok, Rusia, pendekatan geoekonomi, konflik, dominasi AS, penyeimbangan, Kawasan Asia-Pasifik. 
The past decade has brought the phenomenon of new world powers that have the prospect to balance, or even to challenge the domination of the United States. One of them is the possibility of a "strategic triangle" between China, India, and Russia. The idea of the axis between MoscowBeijing-New Delhi was proposed by the former Russian Prime Minister Yevgeny Primakov in 1998, when he visited India (Pant 2006). Once the idea was raised, there were already about 11 trilateral meetings (until 2012) between the Foreign Ministers of the three countries. This suggests, since the first meeting in the General Assembly of the United Nations in 2002 between Foreign Minister Igor Ivanov, Tang Jiaxuan, and Yashwant Sinha (Pant 2005), that the formal communication has been maintained. Based on this background, it appears that the existence of the "strategic triangle" between China-India-Russia cannot be underestimated. However, this paper focus more on China and Russia, as the previous elaboration showed that India were closer to the U.S., rather than balancing or even challenging U.S. hegemony ${ }^{1}$. That is the reason why the focus of this paper was the Sino-Russian order, not the triangle of China-India-Russia.

A lot of analysts have tried to see the potential of "Strategic Triangle". Chengxu (2002) considered that the potential for cooperation among the three countries is quite "bright". He based his argument, among other things, on the ability of the three countries related to the geopolitics, military, natural resources, market forces, and the amount of human resources (Chengxu 2002, 98). Other analyst, such as Acharya (2002) was not too optimistic about the potential for cooperation and the ability of these countries to face the United States. Acharya $(2002,53)$ considers that there are many imbalances between the three countries that may hinder cooperation. However, it is still possible to see that cooperation was held in the context of global issues such as the issue of Human Rights, the threat of fundamentalism and terrorism, as well as humanitarian intervention and international cooperation (Acharya 2002, 54). Some analysts, such as Raman (2004) emphasized the need for enhanced cooperation among the three countries, while Pant (2005 \& 2006) is pessimistic about the potential for three-country cooperation and their potential to balancing the U.S.

\footnotetext{
1 My previous research on this subject elaborates the analysis on the triangle, but for this paper, I had limited the analysis into two-country comparison. This decision was based on several suggestions aroused during the International Conference on International Studies 2012 (in Kuala Lumpur) and PSA-ISS Conference in Budapest (2013).
} 
While the academic debate going on about the potential of Russia, China, and India to counterbalance U.S. domination, we need to see the continuing efforts made by each country. Separately, Russia and China have pronounced many statements and actions that demonstrated their desire to counterbalance the U.S. position. Russia under the leadership of Putin and Medvedev did some provocative things to the U.S., starting from the reactivation of the long-range nuclear bombers (BBC News 2007a), the development of the hydrogen bomb (BBC News 2007b), the support for Iran's nuclear program (Isachenkov 2007), the support for Syria (Pukhov 2012), as well as their rejection of the early efforts of NATO-led bombing against Libya (New York Times 2011). Moreover, Russia's continued effort to explore the Arctic region also poses a potential disturbance between Russia and the United States (Frolov 2007).

On the other hand, China was having a problematic relationship with the U.S. Gill (2007) emphasized that the U.S. relationship with China will be linked to the five cases; the issue of Taiwan, the relations with Japan, the issue of North Korea, the emergence of new regional organizations in Asia, as well as China's relations with the U.S. alliances. In relation to Taiwan, especially after the re-election of President Ma Ying-jeou in the January 2012, it appears there is little chance of turbulence which could lead to the potential for conflict with the U.S., especially with the China-Taiwan economic relations are getting better (Wall Street Journal 2012). The major problem, however, is the China-Japan strained-relations and the South China Sea problem that resulted in the deterioration of China-US relations. U.S. official statement was accusing China as the party who aggravate the conditions in the South China Sea, by strengthening the administrative bodies and put military garrison in Sansha City. U.S. supports of Japan's position in the dispute over Diaoyu Island also led to increased tension between China and the U.S. (Xuetong \& Haixia 2012). On the issue of North Korea, China's position has been to provide ongoing support to the North Korean which increased the concerns that China seemed to balance the position of the U.S., Japan, and South Korea (Gill 2011). The meeting between President Hu Jintao and the uncle of Kim Jong-un, Jang Song Thaek, in August 2012 also indicated the strong support from China to North Korea (Huffington Post 2012).

Related to the bilateral situation, China and Russia have had several positions related to the policies between them against the U.S. Multilateral organization, such as the Shanghai Cooperation Organization (SCO), for example, is considered a counter against U.S. unilateralism and seek 
alliances to counterbalance the U.S. and Europe(Brækhus \& Øverland 2007; Lo 2008). Cooperation between the two countries is also demonstrated by Putin's statement in 2006 that the two countries wanted a multipolar world that benefits their national interests (People's Daily 2006). Within the framework of SCO, both China and Russia have agreed to resist U.S. unilateralism and pushed for a more multipolar world (Isakova 2005).

The case of China and Russia had shown that both countries often have provocative policies towards the U.S. The question then, could both countries balance the U.S. on the global context? Can China-Russia become a dominant player in the context of a multipolar world? I attempt to answer these questions by enriching the debate on the potential of China and Russia to counterbalance the U.S. To that end, this article is divided into several sections. The first part is a theoretical basis that is used in the analysis: the geo-economic approach. This section described the key points on which to establish the analysis. The second part is a comparative geoeconomical aspect of each country, design to highlight the main factors on which to base the economic position of the both countries currently, and to make comparisons among the two. The third section is part of the calculation of the potential for conflict and cooperation among both countries and the U.S., especially within the framework of the Asia Pacific region, as well as the concluding remarks of this article.

\section{Theoretical Consideration: A Geo-Economical Approach}

There is a need to look specifically at the fundamentals of the economy of China-Russia and, at the same time, allow for a predictive analysis of the future of both countries concerned with the relative position of the United States. One of the tools that allow doing that is the geo-economic approach. Geo-economical approach is an approach that uses the relationship between the economy of a country and the geographical aspect. The basics of this approach are the question of "Where is the economic dynamics going? Who is going into an ascending power? Who's going into a declining one? Where and when? At what geopolitical costs and consequences?” There are several major approaches in the study of geo-economics, which is used in this article.

The first is the view of Modelski \& Thompson (1996) on the coevolution between the dynamics of the global economy with the dynamics of global politics. Based on the view of the Kondratieff related to the mastery ofleading economic sector, which is then correlated with Modelski and Thompson's long cycle of global politics, this article departs from Rennstich argument 
(2002) on the importance of leading sector for the global economic control. Grounded on this way of thinking, this article analysed the geo-economical aspects based on the country's ability to master certain leading sectors of the economy. The second approach is the approach expressed by Dicken (2007). One important aspect of the writings of Dicken, which is used in this article, is the main argument that the control of global economy was based on the control over the networks of production and distribution. Unlike Rennstich who emphasized the importance of the mastery of leading sectors, Dicken emphasizes that mastery of the network will be more decisive. In this article, the Dicken's view has become one of the aspects that are the basis of the analysis. The third approach used is the classical approach to geopolitics, which emphasized the ownership of oil and natural resources. Both Harvey (2003) and Klare (2001), although in different contexts, emphasized that ownership of oil and other natural resources are very crucial in analysing the character of the country's economic improvement and predict the future. In this article, the views of the importance of oil and other resources to the third aspect of geoeconomical analysis. The last approach is the view promoted by neoliberal such as Roberts et al. (2003), Herod (2003), and Gertler (1988). In view of this, the basis is the state of entrepreneurship in a country, the existence of a system that supports entrepreneurship and the individual property rights. This view is a basis for a neoliberal geo-economic analysis, conducted in the next section. Based on those theoretical arguments, the next part of this article will be the geo-economical analysis which is based on four approaches that may be used by the state.

\section{The Geo-Economical Approach: Analysing the Sino-Russian Economic Strength}

In this sub-section, the ability of the two countries is analyzed from the geoeconomic perspective described in the previous section. The basic question posed in this section include "Does the state control the leading sectors, or control the production and distribution networks?", "How is the condition of the energy security of both countries?", "Are the economics of these countries based on the mastery of leading sectors, control of production and distribution networks, control of natural resources and energy, or based on the existence of a competitive entrepreneurial climate?". This sub-section starts from the analysis of the basic strength of the Chinese economy, then Russia, to be compared later in this article.

\section{China's Economic Ascendancy: Which Geo-Economical}




\section{Approach?}

The rising economic condition of China has become a global phenomenon in the last two decades. Since Nicholas Kristof wrote the article "The Rise of China" in Foreign Affairs, in 1993, much has been written about China's rapid economic progress and its impact on international or regional political conditions (including Kristof 1993; Segal 1999; Shambaugh, ed. 2005; Acharya 2008; Tang, Li, \& Acharya, eds. 2009; Jacques 2009). This article is not intended to look at the general progress of China, but to evaluate the most important aspect of China's economic progress.

It is indisputable that China has now become a major actor in the context of the global economy. The news released by the Financial Times (2011) revealed that in 2011, China has passed the U.S. position as a major producer of manufactured goods. China's financial performance, related to their proposed loans to developing countries and the strengthening of the position of renminbi, has risen rapidly in the years of 2009-2010 (Jacques 2012). Citing Bergsten et al. (2008), China has become a global economic superpower, as the country with the largest national economy and the growth of an average of 10 percent per year in the last 30 years. The question then, associated with the issue of leading economic sectors, is China mastering specific sectors that enable control of the world economy? Or China is mastering global network of production and distribution? How is the condition of their energy security? Are there any values of entrepreneurship and economic freedom?

I agree with Rennstich's argument (2002), that the leading sector in the contemporary era is the innovation in the field of information and communication technology (ICT). Mastery of ICT and ICT networks, both at local and global level, although it is still being debated, is one of the main aspects of the development of the world economy until 2030 (Rennstich 2002). If so, whether China dominates innovation in this field or not?

I argue that China is not a global player in the field of ICT-related innovations and software. Research conducted by Tschang and Xue (2005) shows that the software industry in China is still in its early stages. In contrast to India, which has a reputation as a producer of software and ICT innovator on a global level, China is still putting more emphasis on the domestic market as the main target of the industry (Tschang \& Xue 2005). Sheehan (2010) also showed that service industries in China, although increasing since 1979, have not been able to drive an increase in China's economic conditions. 
However, it does not mean China does not emphasize the mastery of high technology. Sheehan (2010) noted an increase in the percentage of the service sector in the GDP, which was only about 30 percent in 1979, to be around 40 percent in 2006. This means that, although not yet fulfilling the economic potential, there are efforts to improve the aspects of services in China's economy. In addition, a focus on high technology such as nanotechnology also began in China. Reports by The Guardian (2009) show that China now becoming a major player in the development of nanotechnology, just a step behind the U.S. Bhattacharya \& Bhati (2011) adequately describe China's efforts to become a global player in the field of nanotechnologies, either by filing patents, scientific publications on nanotechnology, the implementation of standards, or through government policy. Therefore, although not a major player in the context of the leading sectors of ICT, there have been efforts by China to pursue aspects of technology through nanotechnology.

Related to the other aspects of geo-economics, as has been argued by many parties, China's progress has been more defined by the ability to be the centre of world manufacturing industry rather than the ability to be the centre of innovation in ICT. Data provided by Yusuf, Nabeshima, and Perkins $(2007,36)$ shows that in 2004 alone, China has 17 percent global textile exports, 24 percent of world clothing exports, 15 per cent of exports of goods and controlled about 8.3 percent of world exports of manufactured goods. This argument was reinforced by the fact that the U.S. position as the world's largest producer of manufactured goods over the last 110 years has been replaced by China in 2011 (Financial Times 2011). As stated by Navarro (2006), the main advantage of China's economy is on the concept of "China Price", i.e. the ability of China to produce goods at a cheaper price and larger quantity. Of course, there is criticism to, borrowing a phrase from Navarro, "China's weapons of mass production". However, we cannot turn a blind eye that the "China Price" has taken China to the leading position in the world economy.

One indicator of the power of China in the context of manufacturing and production-distribution network is that many goods distributed in the world today comes from China, or "made in China". The results of a survey carried out by Li-Ning Co. lead to the facts that the product from China was accepted in the global level, especially as consumers also felt that Chinese goods are already surrounding them (China Daily 2012). This indicates that China is closer to the Global Shift approach, with the emphasis on the mastery of the production network (based on the amount of public 
goods produced in China) and distribution (based on the number of China products distributed in the world). Bapuji's article (2011) on the issue of recalling process of goods from around the world, especially Chinese goods, while emphasizing that there are many factors that led to the withdrawal of a product, illustrates that the Chinese goods were so heavily distributed all over the world so that when there is an issue of withdrawal of goods in the U.S., the impact is quite widespread.

If, in the context of the Global Shift, China has quite a lot of positive value, that is not the case with the energy aspect. Mubah (2011) has shown that China's energy security conditions could potentially lead to the hindrance of China's economic future. Batra \& Khetan (2004) predicted that by 2030, China's oil demand will increase by about two-fold the demand in 2000, while production capacity is only able to meet about 15 percent of those needs. Shalizi (2007) also argued for an increase in energy demand, especially for electricity and transport. Navarro (2006) has also estimated that China's needs of energy, especially oil, will cause conflict in the South China Sea, and against the United States. It showed that from the classical geo-economic approach, the potential for China to become a major world player will be, potentially, hampered by its inability to meet its energy needs and by the impending conflict due to the competition for energy.

Meanwhile, regarding the neoliberal aspects related to entrepreneurship and economic freedom, China is an enigma in that aspect. Contrary to the common belief that China is a communist country, there are aspects of neoliberalism appeared in China, although still within the framework of state control. Bardhan (2010) stated that the private sector in China has started to emerge and the State-Owned Enterprise (SOE) has been increasingly commercial, although still in the constellation of patron-client under the government. Arrighi (2007) has pointed out that although China is not applying the classic patterns of neoliberalism such as the Washington Consensus, but China was implementing a gradualism that is rooted in the competition between the SOEs. From both studies, we can conclude that China is not applying neoliberal principles purely but combined it with the patterns of government control over SOE.

From the above analysis, China is more likely to give priority to the production and global distribution network compared to the mastery of leading technology sectors, as well as the principles of private economic freedom. However, it should be noted that China is on progress in the field of nanotechnology and there are increasing neoliberal competition among 
SOEs. Regarding its energy security, China is vulnerable to the imbalance of energy needs and production capabilities. These become important considerations in the later analysis of the comparison between the ChinaRussia.

\section{Russia's Resurgence: Which Geo-Economical Approach?}

In the Russian situation, the economy is not often talked about as the aspects of the resurgence. Resurgent Russia is usually discussed under the military aspects of identity and conflict (Kerr 1995; Smith 1999; Bugajski, ed. 2002; Isakova 2005; Kanet, ed. 2007). This section explained the major factor in Russia's economic recovery. Is the mastery of leading ICT sectors as well as the production and global distribution network performed as the source of the revival of the Russian economy? Or the basis of the Russian economy is indeed, the sector of energy-related natural resources? How about economic freedom in Russia? These questions were discussed in this sub-section.

After the Soviet collapse in the early 90s, the Russian economy began to experience improvement in 1999. Before the financial crisis of 2008, Russia has experienced GDP growth which reached 6.9 percent per year from 1999 to 2008 (Cooper 2009). However, The Economist noted that since 2000, average GDP growth in Russia account for just about 5 percent (The Economist, 22 December 2011). From these facts, though not as great as China, the Russian economy had been still improving after the Soviet collapse and the financial crisis of 2008.

It appears that many experts agree that one of the main factors in the increasing Russian economic is oil, gas, and natural resources. Cooper (2009, p.8) notes that oil, natural gas, and metal exports become the backbone of Russia's exports, reaching about 79 percent of total exports in 2008. Hanson (2003) has pointed out that the Russian economy is highly dependent on world oil prices; rising oil prices will encourage increased economic conditions, while the decline in oil prices will cause a decline in the condition. This fact is reinforced by the research performed by Oliker et al. (2009) which indicates the fact that the Russian economy is driven by oil and natural gas possessions that Russia has, although not as great as many people imagine. Csaba (2002) examined the economic recovery of Russia from 1999-2001 and found that the increase in global oil prices has been a major factor behind the economic conditions of Russia. From some of the research's results, energy and resource factors shaped the foundation of the Russian economy. 
What about the other aspects of the procurement and mastery of leading ICT sectors and the control over production or distribution networks? In the context of the mastery of ICT, software industry in Russia has not amounted to similar industries as in India. Data from ISTOK-Soyuz (2009) shows that until 2007, the IT sector accounted for only 1.4 percent of GDP. Compare this with the oil and gas sector which accounts for about 18.9 percent of GDP (Oliker et al. 2009). Lonkila's research (2011) showed that the condition of the Russian ICT industry was still in its early stages. However, Lonkila (2011, 46-47) argues that the prospect of this sector in the future is high, with the strength lies in its ability to produce high technology at a low-cost process. From some of the data, it seems clear that although has high potential, but at this time the resurgence in Russian economy has not been stimulated by the progress of Russia's mastery of the ICT sectors.

Related to control over production and distribution networks, in the context of the manufacturing industry, Russia defence industry is very prospective. Research conducted by Oliker et al. (2009) has described how the dynamics that occur in the Russian defence industry. Unfortunately, other studies by Wolf \& Lang (2006) suggests that, despite having ample potential, the arms export industry and Russian defence has not maximized now, as well as the former Soviet era. By grounding on the argument of Oliker et al. (2009) and Wolf \& Lang (2006), the aspects of manufacturing and the control over production and distribution networks, primarily related to the military and high technology such as the aircraft, were not the driving force of the Russian economy.

One of the unique dilemmas of Russian capitalism is linked with the neoliberal approach. When analysed on the Index of Economic Freedom 2012, the Russians are more open in terms of the freedom of doing business compared to China; Russia is ranked 92, while China is ranked 149th. Related to the issue of the freedom of property or ownership of the goods, Russia is ranked 137th. Unfortunately, when compared with the U.S., Russia still lags far behind. Overall, Russia is only ranked 144th, while the U.S. is ranked 10th. Even when compared, Russia lagged China; China is ranked 138th. From the aspect of economic freedom, it seems that Russia still lags China, not to mention the U.S. However, other facts cannot be overlooked when there is a dilemma between dualism and state control of the market economy in Russia. On the one hand, an increasing number of entrepreneurs and privatization that occurred showed a strong push towards a market economy and neo-liberalisation (Wolf \& Lang 2006). 
However, on the other hand, the strong government control, especially in the era of Putin (Csaba 2002) and the existence of the power of the oligarchy and the privatization of natural resources (Guriev \& Rachinsky 2005) eliminates potential aspects of economic freedom with the concentration of ownership to the government and the oligarchs' groups.

Originated from the previous analysis, it appears, like many had argued before, that the resurgence of the Russian economy was driven by control of natural resources and the rise of world oil prices. The fundamental aspects of production and distribution networks of military equipment that was one of the Soviet character turns out not to be the pillar of the Russian economy today. Mastery of leading ICT sectors are also not the engine of economic revival of Russia. Meanwhile, the aspects of entrepreneurship and economic freedom were under controversy, from the impetus of privatization to the control by the government and the oligarchs.

\section{The Geo-Economical Aspect of the Strategic Partnership: A Comparison}

In relations to the Sino-Russian order, there is a need for a clear comparison of the position of the China-Russia regarding the geo-economical aspects. Table 1 shows more clearly how the comparison between them from the point of view of geo-economics.

\begin{tabular}{|l|l|l|}
\hline & China & Russia \\
\hline $\begin{array}{l}\text { Leading Sectors } \\
\text { ICT }\end{array}$ & $\begin{array}{l}\text { Still Low, prefer } \\
\text { nanotechnology }\end{array}$ & $\begin{array}{l}\text { Still Low, high poten- } \\
\text { tial due to technical } \\
\text { advantage }\end{array}$ \\
\hline $\begin{array}{l}\text { Network of Pro- } \\
\text { duction \& Distri- } \\
\text { bution }\end{array}$ & $\begin{array}{l}\text { Driver of Economic } \\
\text { Rise }\end{array}$ & $\begin{array}{l}\text { Still Low, high po- } \\
\text { tential due to defence } \\
\text { and military sectors }\end{array}$ \\
\hline $\begin{array}{l}\text { Oil and Energy } \\
\text { Supply }\end{array}$ & $\begin{array}{l}\text { Crisis potential, due } \\
\text { to high demand } \\
\text { from industry }\end{array}$ & $\begin{array}{l}\text { Driver of Economic } \\
\text { Rise }\end{array}$ \\
\hline $\begin{array}{l}\text { Business Free- } \\
\text { dom \& Property } \\
\text { Rights }\end{array}$ & $\begin{array}{l}\text { 2nd place of the } \\
\text { Three (138th place } \\
\text { in the world) }\end{array}$ & $\begin{array}{l}\text { 3rd place of the } \\
\text { Three (144th place in } \\
\text { the world) }\end{array}$ \\
\hline
\end{tabular}

From Table 1, both countries are in a different position from the 
standpoint of geo-economics. China is more of a poster child of the Global Shift approach, with the emphasis on aspects of global production and distribution networks. On the other hand, Russia was still relying on classical geo-economic aspects, specifically by relying on ownership of natural resources and energy. However, both countries are still far below the U.S. in terms of economic freedom. The result of the analysis determined the analysis in the next section, which concentrated on the potential challenge to U.S. dominance and the probable impact, especially in Asia Pacific.

\section{The Potential Problem: Comparing the Potential to Challenge U.S. Domination}

As the last part of this article, this section is intended to assess the probability of both countries, China and Russia, to balance the domination of the U.S. as well as assessing the potential conflicts that may occur, especially in the Asia Pacific region. I argue that the potential of both countries to balance, or even compete with the U.S. were still quite low. There are several reasons that can be taken into consideration.

Firstly, in the geo-economic aspects, China and Russia was the poster child of a different approach, but the U.S. is still ahead in almost all approaches. Both China and Russia were lagging the U.S. in terms of the ICT. In the context of production and distribution networks, China indeed has overthrown the United States in the year 2011, but it should also be noted that China made it through by relying on more human resources and cheaper labour rates than the U.S. In addition, the condition of the China's manufactured goods which had caused massive recalls should also be the other considerations (Bapuji 2011). Meanwhile, even as one of the world's biggest energy exporters, Russia's economic fragility derived from its dependence on global oil prices. The condition of the Russian economy which was highly dependent on the energy aspects could not be placed in the same level with China, let alone the United States. Meanwhile, both countries simply not in the same level with the United States if we look from the neoliberal approach. Index of Economic Freedom in both countries is still far from the attained individual economic freedom in the U.S. Of the four geo-economical considerations, although in the terms of the macroeconomics both China and Russia have been increasing rapidly, but the fundamental aspect of economic improvement of both countries were still below the U.S. Even if one country could excel at one aspect, the U.S. was still superior in almost every aspect, except the aspect of energy. 
However, the potential for conflict, especially in the Asia Pacific region, were hard to be disregarded. In addition to the possibility of conflict against the U.S., the potential for conflict between both countries also need to be considered. For that, the potential for conflict and cooperation among both countries need to be considered.

In the relations between both countries, there are still possibilities of cooperation. Cooperation between Russia and China has become one of the central aspects of the study of geopolitics (Myasnikov 2002; Lo 2004). However, the potential for conflict between them is still quite high. There are some important foundational arguments. Firstly, both countries need a stable relationship with the West, especially the U.S. Neither China nor Russia can break ties with the U.S., even though it was done for the sake of good relations with one another. Secondly, China and Russia have the history of conflictual relation; China has historically been considering Russia as a greedy, imperialist power, while Russia still have the fears of the emergence of "the yellow peril"; the migration of the people of China to the Russian Far East region (Lo 2008).

Potential conflicts between both countries with the United States in the Asia-Pacific, or potential competition over powers in the region became the last part of this article. Some of the potential for conflicts associated with the condition and the geo-economical aspects has emerged into open conflict. The issue of China's potential energy crises encourages China to search for energy in the South China Sea. The potential conflict between China and Russia with the US and Japan over the disputed Senkaku/Diaoyu Island must not be taken too lightly. In addition, the issue of Taiwan and North Korea will obviously still be the potential problem in the future.

Regarding the multilateral fora, given the position of China's and Russia's economic and cultural contexts that unable to compete with the U.S., it is likely that both will not be too aggressive against U.S. dominance in forums such as ASEAN, ARF, and APEC. However, the potential of conflict, especially when the issues that arise were related to the sensitive issues such as borders and natural resources, it is possible that China and Russia could become more provocative.

In concluding this article, it is important to note that the Sino-Russian order will still be an interesting subject in recent years. This is more due to the expectations of many parties for other forces that can counterbalance U.S. dominance. Unfortunately, as already stated in the analysis section, geoeconomically both countries have not been able to balance, let 
alone compete, with the U.S. Individually, each country have their own problems, so it is quite difficult to challenge the dominant position of the U.S. Bilaterally, although there has been improvement of the relationship, history and future border issue overshadowing the bilateral relations. In this context, it is quite difficult to see the bilateral order of the Chinese and Russian could challenge the current U.S.-based constellation of global politics.

\section{Reference List}

\section{Books}

Acharya, A., 2008. Asia's rising: Who is leading? Singapore: World Scientific Publishing, Co. Pte. Ltd.

Arrighi, G., 2007. Adam Smith in Beijing: Lineages of the twentieth century. London: Verso.

Bapuji, H., 2011. Not just China: The rise of recalls in the age of global business. Hampshire: Palgrave Macmillan.

Bardhan, P., 2010. Awakening giants, feet of clay: Assessing the economic rise of China and India. Princeton, NJ: Princeton University Press.

Bergsten, C.F., Freeman, C., Lardy, N.R., \& Mitchell, D.J., 2008. China's rise: Challenges and opportunities. Washington D.C.: Peterson Institute for International Economics \& Center for Strategic and International Studies.

Bugajski, J. (ed.), 2002. Toward an understanding of Russia: New European perspectives. New York: Council on Foreign Relations.

Csaba, L., 2002. "Russia's political economy", in J. Bugajski (ed.), Toward an understanding of Russia: New European perspectives. New York: Council on Foreign Relations.

Dicken, P., 2007. Global shift: Mapping the changing countours of the world economy. London: SAGE Publications.

Gill, B., 2007. Rising star: China's new security diplomacy. Washington D.C.: Brookings Institution Press.

Harvey, D., 2003. The new imperialism. Oxford: Oxford University Press.

Isakova, I., 2005. Russian governance in the twenty-first century: Geostrategy, geopolitics, and governance. Oxon: Frank Cass.

Jacques, M., 2009. When China rules the world: The end of the Western 
world and the birth of a new global order. New York: The Penguin Press.

Kanet, R. (ed.), 2007. Russia: Re-emerging great power. Hampshire: Palgrave Macmillan.

Klare, M.T., 2001. Resource wars: The new landscape of global conflict. New York: Owl Books.

Lo, B., 2008. Axis of convenience: Moscow, Beijing, and the new geopolitics. Baltimore, MD: Brookings Institution Press.

Lonkila, M., 2011. Networks in the Russian market economy. Hampshire: Palgrave Macmillan.

Modelski, G. \& Thompson, W., 1996. Leading sectors and world power: The coevolution of global politics and economics. Columbia: The University of South Carolina Press.

Navarro, P., 2006. The coming China wars: Where they will be fought and how can they be won. New Jersey: FT Press.

Oliker, O., Crane, K., Schwartz, L.H., \& Yusupov, C., 2009. Russian foreign policy: Sources and implications. Santa Monica, CA: RAND Corporation.

Shalizi, Z., 2007. "Energy and emissions: Local and global effects of the giants' rise", in L.A. Winters \& S. Yusuf (eds.), Dancing with giants: China, India, and the global economy. Washington D.C. \& Singapore: The World Bank \& The Institute of Policy Studies.

Shambaugh, D. (ed.), 2005. Power shift: China and Asia's new dynamics. Berkeley \& Los Angeles: University of California Press.

Sheehan, P., 2010. "Beyond industrialization: New approaches to development strategy based on the service sector", in A.U. SantosPaulino \& G. Wan (eds.), The rise of China and India: Impacts, prospects, and implications. Hampshire: Palgrave Macmillan.

Tang, S., Li, M., \& Acharya, A. (eds.), 2009. Living with China: Regional states and China through crises and turning points. Hampshire: Palgrave Macmillan.

Tschang, T., \& Xue, L., 2005. "The Chinese software industry”, in A. Arora \& A. Gambardella (eds.), From underdogs to tigers: The rise and growth of the software industry in Brazil, China, India, Ireland, and Israel. Oxford: Oxford University Press.

Wolf, C., \& Lang, T. (2006). Russia's economy: Signs of progress and retreat on the transitional road. Santa Monica, CA: RAND Corporation.

Yusuf, S., Nabeshima, K., \& Perkins, D.H., 2007. "China and India reshape global industrial geography”, in L.A. Winters \& S. Yusuf(eds.), Dancing 
with giants: China, India, and the global economy. Washington D.C. \& Singapore: The World Bank \& The Institute of Policy Studies.

\section{Journal Articles}

Acharya, A., 2002. "Political cooperation between India, China and Russia: Problems and prospects", China Report, 38(1): 49-55.

Batra, R.K. \& Khetan, A., 2004. "Russia-China-India energy cooperation", China Report, 40(2), 169-182.

Bhattacharyan S., \& Bhati, M., 2011. "China's emergence as a global nanotech player: Lessons for countries in transition", China Report, 47(4), 243-262.

Brækhus, K. \& Ǿverland, I., 2007. "A match made in heaven? Strategic convergence between China and Russia", China and Eurasia Forum Quarterly, 5(2), 41-61.

Chengxu, Y., 2002. "The possibility and prospects for developing Russia -India -China relations", China Report, 38(1): 95-99.

Cooper, W.H., 2009. "Russia's economic performance and policies and their implications for the United States", CRS Report for Congress, RL34512, Congressional Research Service.

Gertler, M.S., 1988. "The limits to flexibility: Comments on the postFordist vision of production and its geography", Transactions of the Institute of British Geographers, 13(4), 419-432.

Gill, B., 2011. "China's North Korea policy: Assessing interests and influences", USIP Special Report, No.283.

Guriev, S., \& Rachinsky, A., 2005. "The role of oligarchs in Russian capitalism", The Journal of Economic Perspectives, 19(1), 131-150.

Hanson, P., 2003. "The Russian economic recovery: Do four years of growth tell us that the fundamentals have changed?", Europe-Asia Studies, 55(3), 365-382.

Herod, A., 2003. "Geographies of labor internationalism”, Social Science History, 27(4), 501-523.

Kerr, D., 1995. "The new eurasianism: The rise of geopolitics in Russia's foreign policy”, Europe-Asia Studies, 47(6), 977-988.

Kristof, N., 1993. "The rise of China”, Foreign Affairs, 72(5), 59-74.

Lo, B., 2004. "The long sunset of strategic partnership: Russia's evolving China policy", International Affairs, 80(2), 295-309. 
Mubah, A.S., 2011. "Energy crisis threat: A challenge for the rise of China", Jurnal Global \& Strategis, 5(2), 169-184.

Myasnikov, V., 2002. "Strategic interaction between Russia and China: A basis for development of bilateral cooperation", China Report, 38(1), 77-86.

Pant, H.V., 2005. "The Moscow-Beijing-Delhi 'strategic triangle': An idea whose time may never come”, Crossroads, 5(2): 19-46.

, 2006. "Feasibility of the Russia-China-India "strategic triangle": Assessment of theoretical and empirical issues", International Studies, 43(1): 51-72.

Raman, B., 2004. "Counter-terrorism: India-China-Russia cooperation", China Report, 40(2): 155-167.

Rennstich, J.K., 2002. "the New Economy, the Leadership Long-Cycle and the Nineteenth K-Wave", Review of International Political Economy, 9(1): 150-182.

Robert, S., Secor, A., \& Sparke, M., 2003. "Neoliberal geopolitics", Antipode, 35(5): 886-897.

Segal, G., 1999. “Does China matter?”, Foreign Affairs, 78(5): 24-36.

Smith, G., 1999. "The masks of proteus: Russia, geopolitical shift and the new eurasianism", Transactions of the Institute of British Geographers, 24(4): 481-494.

\section{Online Sources}

BBC News, 2007a. "Russia Restarts Cold War Patrols" [online]. in http:// news.bbc.co.uk/2/hi/europe/6950986.stm [accessed 11 May 2009].

, 2007b. "Russia Tests Giant Fuel-air Bomb" [online]. in http:// news.bbc.co.uk/2/hi/europe/6990815.stm [accessed 11 May 2009].

China Daily, 2012. "'Made in China' gains acceptance" [online]. in http:// www.china.org.cn/china/2012-06/16/content_25664766.htm [accessed 9 October 2012].

Financial Times, 2011. "China noses ahead as top goods producer" [online]. in http://www.ft.com/intl/cms/s/o/oo2fd8fo-4d96-11eo-85e4o0144feab49a.html\#axzz29LAbs8pH. [accessed 9 October 2012].

Frolov, V., 2007. "The coming conflict in the Arctic: Russia and US to square off over Arctic energy reserves" [online]. in http://www. globalresearch.ca/the-coming-conflict-in-the-arctic [accessed 8 October 2012]. 
Huffington Post, 2012. "China North Korea relations: President $\mathrm{Hu}$ Jintao gives show of support for impoverished ally" [online]. in http://www.huffingtonpost.com/2012/o8/17/china-north-korearelations_n_1793854.html [accessed 8 October 2012].

Isachenkov, V., 2007. "Putin warns against attacks on Iran" [online]. in http://news.yahoo.com/s/ap/20071016/ap_on_re_mi_ea/iran_ russia [accessed 10 May 2009].

ISTOK-SOYUZ, 2009. "National ICT sector and policy appraisal report" [online]. in http://www.eeca-ict.eu/uploads/dmdocuments/ National_report_Russia_Final.pdf [accessed 8 October 2012].

Jacques, M., 2012. "Why do we continue to ignore China's rise? Arrogance" [online]. in http://www.guardian.co.uk/world/2012/mar/25/chinarise-ignorance [accessed 10 October 2012].

People's Daily, 2006. "China-Russia strategic partnership positive element in world order: Putin" [online]. in http://english.people.com. cn/200603/20/eng20060320_251859.html [accessed 10 May 2009].

Pukhov, R., 2012. "Why Russia is backing Syria" [online]. in http:// www.nytimes.com/2012/07/07/opinion/why-russia-supports-syria. html?_r=1\& [accessed 9 October 2012].

The Economist, 2011. "Focus: Russia's economy" [online]. in http://www. economist.com/blogs/graphicdetail/2011/12/focus-1?zid =295\&ah $=0$ bca374e65f2354d553956ea65f756eo [accessed 11 October 2012].

The Guardian, 2009. "China's giant step into nanotech" [online]. in http:// www.guardian.co.uk/technology/2009/mar/26/nanotechnologychina [accessed 9 October 2012].

The New York Times, 2011. "Russia recognizes Libya rebels as world leaders meet" [online]. in http://www.nytimes.com/2011/o9/o2/world/ africa/o2nato.html?pagewanted=all [accessed 9 October 2012].

Wall Street Journal, 2012. "Taiwan vote shows doubt about China" [online]. in http://online.wsj.com/article/SB1000142405297020455 5904577162143105033610.html [accessed 1 October 2012].

Xuetong, Y., \& Haixia, Q., 2012. "How to avoid a U.S.-China cold war" [online]. in http://thediplomat.com/china-power/u-s-chinafrenemies-strategy-prevents-cold-war/ [accessed 8 October 2012]. 